\title{
ONLINE TEACHING - SYSTEMS APPROACH: QUESTIONS AND ANSWERS
}

\author{
Olga Kosheleva \\ Ph.D. (Phys.-Math.), Associate Professor, e-mail: olgak@utep.edu \\ Vladik Kreinovich \\ Ph.D. (Phys.-Math.), Professor, e-mail: vladik@utep.edu \\ University of Texas at El Paso, El Paso, Texas 79968, USA
}

\begin{abstract}
At a recent International Forum on Teacher Education (Kazan, Russia, May 27-29, 2020), special sessions were devoted to questions related to online teaching - in view of the recent forced world-wide transition to online-only education. This article summarizes, in a systematic way, issues discussed at these sessions.
\end{abstract}

Keywords: online teaching, pedagogy, communication skills.

\section{Introduction}

Online-only teaching is a new territory for all of us, This is both bad news and good news:

- it is bad news because we cannot use ready answers, but

- it is good news because we cannot use ready answers - so we all need to improvise, we all have a chance to make a significant contribution.

The following text describes our experience and experience of our colleagues. Do not expect full and final answers, it is up to us all to experiment, analyze and make it all better - but while we are doing this, here are possible answers to the questions raised during the special sessions of the VI International Forum on Teacher Education (Kazan, Russia, May 27-29, 2020) [1].

\section{Issues}

With the recent world-wide transition to online learning, questions arise about all the stages of the teaching process:

- The teaching process starts with dividing students into groups. For online teaching, what is the optimal size of the group?

- Once the groups are fixed, we need to start delivering material to the students. What is the best way to deliver material? Should it be synchronous or asynchronous? How can we use the experience of video lectures and open universities? 
- How important is feedback?

- How much homework to assign?

- How to test and how to grade the tests?

There are also general questions:

- How to motivate students to study?

- How to make it easier for students and for instructors?

- How to maintain student health?

- How to take special circumstances into account:

- gifted and talented students,

- special education students,

- students from disadvantaged families?

- How to design an online class with limited resources in limited time?

Also, questions about the future:

- Does online teaching work at all? Are there disciplines where it does not work?

- In general, what is the future of online education?

- In view of this future, how to best prepare future instructors?

\section{How to Organize the Teaching Process}

How many students in a group. The main limitation is the ability of the instructor to provide regular feedback to all the students. The usual recommendation is to have no more than 25 students in an online class. This is, by the way, a general recommendation for a regular school class as well, the only difference is that:

- for normal learning, it is just a recommendation; smaller classes are better for students, but larger classes are manageable too;

- however, for online learning, larger classes become unmanageable: teachers overwork, students fail.

If there are teaching assistants, then larger classes are also maintainable.

Synchronous vs. asynchronous. For students, synchronous is clearly better, this way they get feedback right away. For teachers, it is also better: they do not need to record every detail, they can be flexible - slow down or speed up depending on student feedback. Both students and teachers can ask questions and get answers right away - as in a face-to-face class. 
Unfortunately, bandwidth limitations do not allow all classes to be synchronous.

How can we use the experience of video lectures and open university? At first glance, online teaching is nothing new. For example, video lectures have been circulating for some time, MOOCs (massive online courses) were based on them, and open universities have been successfully producing specialists in many countries.

We can definitely use some technical ideas, but there is a big difference:

- MOOCs and open university were for enthusiastic students, and now we need to teach everybody,

- even for enthusiastic students, for many popular MOOCs, success rate was below $10 \%$; clearly, this is inappropriate for general education.

So, we need to go beyond this experience.

How important is feedback? Feedback is crucial for education. If it was not so, there would be no need for teachers, only for graders: once students learn how to read, they would be able to study from the textbooks. In reality, a few students can do it, but most students cannot.

How much homework to assign? Homeworks help students learn. On the other hand, if we assign too much homework, students get overworked, and we instructors get overworked. So, a natural idea is to decide how much time students should be spending on homework, and assign accordingly.

At the university level, the usual recommendation is $2-2.5$ hours at home for each lecture hour. At the K-12 school level, the proportion is much smaller, usually less than 1.

What if this requires too much grading? One idea is not to give detailed comments in each homework, post common mistakes instead. Another idea is not to grade everything, to grade only randomly selected tasks. For example, we assign problems 1-4 but grade only problems 1 and 3 . For math problems, we can also use automatic grading systems like the one used in ALEKS [2]

How to test and how to grade the tests? A big concern is cheating, which is easier online. A straightforward solution is to install cameras watching students during the test.

We can also use the usual tricks: The best is to have individualized questions, so that students do not copy from each other. For example, in math problems, we can use a student-related number as one of the inputs. This, however, requires a lot of work when grading.

Less work is needed if we have a few different versions of the test. If even this is too difficult, we can have test questions scrambled differently for each student.

Emphasis should be on open-book open-notes questions, not on memorization questions. (This is, by the way, the usual pedagogical advice.)

How to decrease time spent on grading tests? We can use the same ideas as for homeworks. 


\section{General Questions}

How to motivate students and keep their attention? This is a difficult question already in a regular class. For this, pedagogical students usually take a special course on class management. Online, this is even more complicated:

- there are many more distractions at home than in the classroom,

- and there is no contagion effect - when interest of others keeps students more interested.

So, we need to use more of usual class management techniques. In particular, we need to make our materials and our presentations even more entertaining.

How to make it easier for students and for instructors? The most important thing is to keep work-life balance. We can - and did - work overtime for two months, but it is not possible to overwork for a longer time. We need to allocate time for teaching, and stick to it. Students have it easier: when they have too many assignments, they stop doing them.

It is not being cruel to students, it is being realistic. Normally, no one will seriously answer all student's phone calls right away. Similarly, we cannot answer their emails right away - and maybe, while the student waits for an answer, the student will find his/her own solution.

How to maintain student health? This is a difficult question. Students need exercise, $\mathrm{PE}$ is a must. Something needs be done about vision: sitting in front of a computer is not good for the eyes.

How to take special circumstances into account? Gifted and talented students seem to excel in this new mode - at least this is anecdotal evidence.

The situation with special education students is much more complicated. There are international standards requiring all online materials to be accessible to people with disabilities. Most software tools have way to accommodate these standards; we need to learn this.

A special problem is students from disadvantaged families. These students need help: loaning equipment, donating equipment, computers in public places, etc.

How to design an online class with limited resources in limited time? There are specialists in online learning, there are instructions and textbooks on this topic. However, at present, following all these instructions is not realistic. For example, in the past, at our university, an instructor had to take a 2-month intensive course in online teaching, and then, he/she spent several months designing a class.

With a switch to online, we cannot afford this luxury. Let us just do it. The result will be imperfect, we will improve it as we start teaching.

\section{Future of Online Teaching}

Does online teaching work? Until Spring 2020, there were two main opinions:

- online learning is the revolutionary future, it will make learning much better, 
- online learning is a disaster promoted by politicians and theoreticians who never taught in real schools.

So far, the experience is that it worked, even with improvised imperfect teaching:

- it was not as good and spectacular as enthusiasts promised, but

- it was not as disastrous as opponents predicted.

Even in disciplines like medicine and electrical engineering, a lot of teaching moved online. In medicine etc., some face-to-face is needed. Math, computer science, etc., if needed, can be all online.

What is the future of online education? This depends on us. The more experience we gain, the better will be our classes, the more effective will be online teaching.

Good news is that online teaching does not save money. It is good news because there are no incentives for politicians to force us into more online teaching.

Ultimately, we, instructors, are the specialists. We shall decide - and we will decide - how much learning will be online.

In view of this future, how to best prepare future instructors? Definitely we need more classes on online teaching. These classes should be required for all future instructors, they shall be a must for teacher's continuing education.

However, even without these classes, students will learn - from their own experience. Consciously or not, we all teach largely the way we were taught. So, if we teach our students fully or partly online - as we do now - they will learn how to do it.

And let us all hope that in the future, online learning will be used only because it is efficient!

\section{Acknowledgments}

This work was supported in part by the US National Science Foundation grants 1623190 (A Model of Change for Preparing a New Generation for Professional Practice in Computer Science) and HRD-1242122 (Cyber-ShARE Center of Excellence).

The authors are greatly thankful to all the participants of the VI International Forum on Teacher Education (Kazan, Russia, May 27-29, 2020), especially to Mourat Tchoshanov (University of Texas at El Paso) and to Gulshat Shakirova (Kazan Federal University, Russia), for valuable discussions.

\section{REFERENCES}

1. VI International Forum on Teacher Education, Kazan, Russia, May 27-29, 2020. URL: http://ifte.kpfu.ru/en/home-page/.

2. Assessment and LEarning in Knowledge Spaces (ALEKS), a web-based, artificially intelligent assessment and learning system. URL: http://www.aleks.com.

3. Littlewood J.E. A Mathematician's Miscellany. Methuen, London, 1953. 


\section{A Every Cloud Has A Silver Lining: Positive Side of Spring 2020 Online-Only Teaching}

What happened: a brief reminder. For a significant part of Spring 2020, the whole world was forced to switch to online-only (remote) teaching. This was not just synchronous online teaching, when the only difference is spatial separation. Because of bandwidth limitations, a significant portion of teaching was asynchronous. Natural questions are:

- what can we learn from this experience?

- how can we use this experience in our future teaching?

- what are related open questions?

Online-only experience: challenges for students. Many students are accustomed to get most of the material either directly from the teacher, or at least in the environment which is actively controlled by a teacher. In the asynchronous online-only regime, students had to learn, to a larger extent, on their own.

Another problem of asynchronous learning is asking questions. Many students are still learning how to ask questions. In face-to-face teaching, it is not that critical: a teacher asks guiding (clarifying) question(s), and, after several iterations, the question is answered. In an asynchronous regime, a reply may follow after several hours, so this may not work. As a result, some questions remain unclear - thus unanswered - for a longer time.

But there were also positive aspects. When overcoming challenges, we - and students - gained some skills. We also gained some material advantages: new content material, new platforms. We gained a better understanding of students' limitations and possibilities. It is important to learn as much as possible from this unique experience.

Material aspects. The first visible positive outcome is that a large amount of new content material was posted. Some of this material was prepared in a rush, looks raw. Now we can polish it, make it more understandable (and more entertaining). This will be all good to use in the future, both for face-to-face and for online learning.

Many software platforms have been developed and adjusted for online teaching. This we can also use in the future.

What skills students gained: direct gain. With online-only teaching, students had to master the skill of understanding the material largely on their own.

Why is this important? In the modern world, acquired knowledge becomes outdated fast, everyone needs to learn new things. In real life, a significant part of this lifelong learning does not come from formal schooling. We learn from books, from papers, etc. This learning is not easy - especially immediately after a school or university, where all the materials are thoroughly prepared by professionals, so that learning can be easy. New ideas, new techniques are rarely that clear. As 
cited in a popular book [3] by the 20th century mathematician John Littlewood, "A mathematician's reputation rests on the number of bad proofs he has given" (here, "bad", of course, means difficult to understand). Ability to learn on your own, from not perfectly clear texts, can help students become 21 century citizens.

It will also help students - who had to miss classes - catch up, because when catching up, a student is, to a larger extent, on his/her own.

It will also help on standardized tests, where a clear understanding of written questions is crucial.

What skills students gained: indirect gain. By realizing that an unclear question may not help, students learn to ask clear questions. This skill is very important for learning: it helps to pinpoint what was not clear, and where others (e.g., teacher) can help.

This can also help in real life - ability to explain oneself clearly is important in workplace. The experience of communicating online prepares students for remote collaboration, and remote collaboration is an important part of the modern workplace.

What else? Let us brainstorm together!

\title{
ОНЛАЙН-ОБУЧЕНИЕ - СИСТЕМНЫЙ ПОДХОД: ВОПРОСЫ И ОТВЕТЫ
}

\author{
О. Кошелева \\ к.ф.-м.н., доцент, е-mail: olgak@utep.edu \\ В. Крейнович \\ к.ф.-м.н., профессор, е-mail: vladik@utep.edu \\ Техасский университет в Эль Пасо, США
}

\begin{abstract}
Аннотация. На недавнем Международном форуме по педагогическому образованию (Казань, Россия, 27-29 мая 2020 г.) специальные сессии были посвящены вопросам онлайн-обучения в связи с недавним вынужденным всемирным переходом к онлайн-образованию. В этой статье систематически обобщаются вопросы, обсужденные на этих сессиях.
\end{abstract}

Ключевые слова: онлайн-обучение, педагогика, коммуникативные навыки.

Дата поступления в редакцин: 1.06.2020 